This is an electronic reprint of the original article. This reprint may differ from the original in pagination and typographic detail.

Author(s): Kontinen, Tanja; Ojala, Arto

Title: $\quad$ Social capital in relation to the foreign market entry and post-entry operation of family SMEs

Year: $\quad 2011$

Version:

Please cite the original version:

Kontinen, T. \& Ojala, A. (2011). Social capital in relation to the foreign market entry and post-entry operation of family SMEs. Journal of International Entrepreneurship, $9(2), 133-151$.

All material supplied via JYX is protected by copyright and other intellectual property rights, and duplication or sale of all or part of any of the repository collections is not permitted, except that material may be duplicated by you for your research use or educational purposes in electronic or print form. You must obtain permission for any other use. Electronic or print copies may not be offered, whether for sale or otherwise to anyone who is not an authorised user. 


\title{
Social capital in relation to the foreign market entry and post-entry operations of family SMEs
}

\author{
Tanja Kontinen and Arto Ojala, University of Jyväskylä
}

\begin{abstract}
Scholars in the discipline of international entrepreneurship have mainly studied rapidly internationalizing firms. However, the majority of entrepreneurial firms are familyowned businesses (85\% of all firms in the EU and the USA). Research on family business has focused on the importance of bonding social capital whereas, despite its importance, bridging social capital has not so far attracted much attention. It has been argued that bridging social capital plays an important role in firms' internationalization processes. The purpose of this article is to examine the role of bridging social capital in the initial entry and post-entry operations of eight family SMEs with regard to the French market. We found that in foreign market entry social capital generally had a serendipity role, based on weak and intermediary relationships. In the post-entry situation the role of strong and formal ties emerged strongly, and social capital most commonly took on efficacy or liability roles. Thus, it seems that the social capital of family entrepreneurs is limited to their strong bonding social capital, and perhaps to their strong national social capital. However, when such firms start to internationalize, they have to find new networks to gain the bridging social capital that will enable foreign operations. It seems that having a limited number of international ties drives family SMEs to search for relevant contacts at international trade exhibitions and trade fairs.
\end{abstract}

Keywords: family SMEs, foreign market entry, social capital

\section{Acknowledgements}

The authors would like to thank the anonymous reviewers and the editor for their insightful comments and suggestions for improving the manuscript. The research has been generously funded by the Foundation for Private Entrepreneurs and the Eemil Aaltonen Foundation.

\section{INTRODUCTION}

The field of international entrepreneurship has commonly focused on rapidly internationalizing firms (Dimitratos and Jones 2005). Scholars have called for research that would take in aspects of international entrepreneurship beyond early internationalizing firms (Young et al. 2003), and which would include different types of enterprise (Dimitratos and Jones 2005). In fact, studies combining family business research and international entrepreneurship are now emerging, and there has been a call for more research specifically on the internationalization of family firms (Graves and 
Thomas 2008; Sciacia et al. in press). In both of these disciplines, networks and social capital have been seen as important (e.g. Coviello 2006; Graves and Thomas 2004).

It has been suggested that social capital may be especially strong in family-owned businesses, because of the unification of ownership and management (Salvato and Melin 2008). A family business is an embodiment of the aspirations and capabilities of the family members, and the social element it embodies affects the decisions that determine its strategy, operations, and administrative structure (Chrisman et al. 2005). This bonding social capital of family firms, also called family capital, is a well-researched topic (e.g. Arregle et al. 2007; Salvato and Melin 2008). In addition, bridging social capital is important for family firms (Arregle et al. 2007), especially in the context of their internationalization. However, (at least in the context of family firms) this topic remains under-researched (Arregle et al. 2007; Graves and Thomas 2004; Kontinen and Ojala 2010). The need to study the bridging social capital of family businesses has also been noted by Coviello (2006), who argued that there may be a difference between the network formation of rapidly internationalizing new ventures and family businesses. With these considerations in mind, this paper reports a study on eight family-owned small and medium-sized enterprises (SMEs) ${ }^{1}$. The study investigated the role of social capital in the foreign market entry (FME) of the enterprises, and in the possible operational changes following market entry.

In this paper, we discuss the phenomenon of social capital in terms of structural dimensions (i.e. as being strong/weak, formal/informal/intermediary) and economic dimensions (involving efficacy/serendipity/liability). Thus we seek first of all to contribute to the field of international entrepreneurship by expanding research beyond early internationalizing firms. Secondly, we wish to contribute to family business studies through an investigation of the bridging social capital of family firms, i.e. by taking up an under-researched topic. Thirdly, the study is intended to contribute to the field of social capital in the context of internationalization, through an investigation of family-owned SMEs - a perspective seen as lacking within organizational research (Dyer 2003) - and by investigating social capital in the context of FME and post-entry operations in a particular target country. This approach builds on the studies of Chetty and Agndal (2007) and Agndal et al. (2008), who studied social capital in the general internationalization pattern of SMEs. Fourthly, we here respond to the call made by Pedersen et al. (2002), who suggested that current literature on foreign operation modes is static, due to the fact that researchers have neglected the changes that may take place following market entry.

The detailed objective of this paper is to answer the following research questions: 1) What types of social capital do family SMEs utilize in their FME and post-entry operations? In other words, it is important to know what types of tie (formal, informal or intermediary) family SMEs utilize in their FME and post-entry operations, and whether these ties are strong or weak. This kind of knowledge can help us to achieve an understanding of how these ties are formed and utilized, and how they affect the FME

\footnotetext{
${ }^{1}$ The definitions of family firm and SME can be found in the methods section of this article.
} 
and post-entry operations. 2) What kind of role does social capital have in these contexts? This means that we shall examine whether family SMEs use the serendipity, efficacy, or liability role of social capital in their FME and post-entry operations. By investigating these aspects, it will be possible to find out how the FME is triggered by social capital, and how changes in social capital affect post-entry operations. All in all, in this case study we aim to extend existing social capital theories to a new context, namely the internationalization of family SMEs.

The paper is organized as follows: we begin with a discussion of the concept of social capital, and more specifically, its types and roles within and subsequent to FME. Secondly, the specific features of family SME internationalization are discussed. Thirdly, the methodological issues of the paper are elaborated. Thereafter, the findings of the study are presented and discussed. In the concluding section, the contributions and limitations of the study are considered.

\section{THEORETICAL BACKGROUND}

\section{Social capital}

The resources available to actors in a network of relationships can be called social capital (e.g. Adler and Kwon 2002). This means that social ties between individuals can be used for a variety of purposes that may result in benefits for actors within the network (Adler

and Kwon 2002; Nahapiet and Ghoshal 1998). Burt (1992) claims that social capital, rather than financial or human capital, is the most significant factor contributing to competitive success in all types of firms. Nahapiet and Ghoshal $(1998,243)$ define social capital as "the sum of the actual and potential resources embedded within, available through, and derived from the network of relationships possessed by an individual or social unit."

Social capital differs from other types of capital, such as financial, physical, or human capital. It is a form of capital that is not located within a certain place, being embedded rather in relationships between actors in a social network (Adler and Kwon 2002; Coleman 1988; Nahapiet and Ghoshal 1998). Adler and Kwon (2002) also argue that social capital is a long-lived asset that can be used for different purposes, and that it can compensate for a lack of other types of capital. However, social capital also requires maintenance. It has to be regularly renewed and reconfirmed if it is to keep its efficacy (Adler and Kwon 2002).

Social capital is dynamic, since it changes over time (e.g. Larson and Starr 1993). It may increase or decrease as firms deepen existing relationships, establish new ones, and end problematic ones (Rauch 2001). However, social capital is not a "universally beneficial resource" (Nahapiet and Ghoshal 1998, 245). For instance, a closed network 
can limit the group's access to new information and new ways of doing things, leading to reduced performance for the firm. The less social capital a firm has, the more it is exposed to opportunistic behavior, and the more difficult it becomes to build long-term relationships (Walker et al. 1997).

The structural, or architectural, dimension of social capital refers to the pattern of connections between actors, and the relational dimension to resources attainable through the structural dimension, such as trust and trustworthiness (Granovetter 1992). In studies on external relations - in other words on bridging social capital - the focus is on the relations an actor maintains with actors outside his or her network (Adler and Kwon 2002). In studies on ties among actors within a collectivity, the focus is on internal or bonding social capital (Adler and Kwon 2002; Yli-Renko et al. 2002).

\section{Types of social capital}

To possess social capital, a person must have relationships with others (Portes 1998) and access to resources embedded in these relationships (Sobel 2002). Thus, it is important to study how ties between people are developed and structured. Social capital ties can be regarded as strong or weak. In previous research, the strength of the tie has been considered from a number of perspectives, including the following: closeness (Marsden and Campbell 1984), trust (Jack 2005; Singh 2000), mutual respect (Jack 2005), and commitment (Hite 2003). As was pointed out by Marsden and Campbell (1984), the use of frequency and duration as a measure of the strength of a tie can be misleading, and hence these variables are not applied here. Using a modification of the definition provided by Söderqvist and Chetty (2009), in the present research a strong tie is defined as one which is close, and which is based on trust, mutual respect, and commitment. By contrast, a weak tie is "a superficial tie not yet based on strong trust and where the parties do not know each other well and are not emotionally close to each other" (Söderqvist and Chetty 2009, 9).

An individual can have only a certain number of strong ties because of the maintenance costs associated with intimate relationships (Singh 2000). By contrast, the number of weak ties can be high. These weak ties do not require high maintenance, but can significantly help the entrepreneur in accessing information. Granovetter (1973) argues that weak ties act as bridges to sources of information not necessarily contained within an entrepreneur's immediate (strong-tie) network: because entrepreneurs interact with weak ties only occasionally, it is likely that such ties will provide more unique information than strong ties. This is in accordance with the findings of Burt (2004), to the effect that that new ideas tend to emerge through weak ties between separate social clusters. However, Granovetter (1985) argues that strong ties are more trustful, as they consist of emotional bonds. This increases the willingness to offer advice and provide valuable information (Singh 2000). In an empirical study, Agndal et al. (2008) found that both direct ties (cf. strong ties) and indirect ties (cf. weak ties) ties were important to all their case firms in relation to FME. Their findings also suggested that direct 
relationships are important in the early phase of the FME, whereas indirect relationships have a more dominant role in later phases.

In addition to strong and weak ties, the structure of network ties can be divided into formal ties, informal ties, and intermediary ties (Ojala 2009). The strength of the tie is not dependent on whether the tie is formal, informal, or intermediary: Söderqvist and Chetty (2009) found that both strong and weak ties can exist in different types of relationships. A formal tie involves a relationship with other firms based on business or market relationships (Adler and Kwon 2002; Coviello and Munro 1997).Thus, Adler and Kwon (2002) explain that in market or business relationships, products or services are exchanged via money or barter. However, it can be argued that these relationships are also embedded within social ties and are thus essentially social (Adler and Kwon 2002; Granovetter 1985). Informal ties, on the other hand, are related to relationships with friends and family members (Coviello 2006; Krackhardt and Hanson 1993; Larson and Starr 1993). However, the boundary between the formal and informal ties is not always clear. As Larson and Starr (1993) note, informal ties may become formal and vice versa. In the intermediary tie, there is no direct contact between the seller and the buyer. However, there is a third party, such as an export promotion organization or an organizer of an exhibition, and that party facilitates the establishment of the network tie between the buyer and the seller. In contrast to formal ties, there are no business transactions between the buyer and the intermediary or between the seller and the intermediary (Ojala 2009). These intermediary ties can provide links between actors in different markets and consequently initiate international business activities between the seller and the buyer (Oviatt and McDougall 2005).

Larson and Starr (1993) argue that the network ties of a firm evolve from informal ties to more formal ties during organization formation. However, recent studies related to rapidly internationalizing firms contradict this assumption (Chetty and Wilson 2003; Coviello 2006). For instance, Chetty and Wilson (2003) also found that early internationalizing firms focus on formal networks whereas less international firms rely more on informal networks.

\section{Roles of social capital}

The internationalization process of firms can be viewed as a process of developing and accessing social capital, since firms initiate, establish, and deepen ties during internationalization (Johanson and Vahlne 2006). Chetty and Agndal (2007) and Agndal et al. (2008) found that in the FME of SMEs, social capital was linked to efficacy and serendipity roles, whereas in the context of post-entry mode change the role of liability was also encountered. The efficacy role refers to the usefulness of a firm's social capital and how it enables market entry or a mode change (Agndal et al. 2008). For instance, interactions between firms increase their knowledge of each other and enable each firm to access the partner's knowledge (Yli-Renko et al. 2002). This helps in acquiring knowledge of new market opportunities, and it increases the efficacy of a firm's social capital. Chetty and Agndal (2007) found that the efficacy role of social capital is 
highlighted in cases where the need for information changes and where close interaction with partners is important. This can trigger a mode change from a low-control mode to a high-control mode. Agndal el al. (2008) argue that especially in initial FMEs, the efficacy role of social capital has an important role.

The serendipity role of social capital is highlighted when the FME or a post-entry mode change is triggered by a chance occurrence involving an external party (Chetty and Agndal 2007). Such an unexpected event is not initiated by the firm itself but by serendipity; the implementation of changes is dependent on the firm's responses to new opportunities emerging from networks (Crick and Spence 2005; Ellis 2000). Chetty and Agndal (2007) found that serendipity plays an important role when firms establish joint ventures or subsidiaries based on the initiatives of partners or employees. These unexpected opportunities may be triggered by a firm's weak ties, emphasizing the important role of weak ties in serendipitous events. The findings of Agndal et al. (2008) indicate that in FME the serendipity role of social capital becomes more influential when a firm is entering a geographically or psychologically distant market. This would also suggest that serendipity has a more dominant role in later FMEs. However, Crick and Spence (2005) found that serendipity has an important role in both initial and later FMEs, but that it is highly dependent on managers' capability to react to and seize the new opportunities that have arisen.

The liability role of social capital refers to problems caused by social capital (Chetty and Agndal 2007). It refers to a change in social capital that "occurs as a result of the high costs and amount of time required to monitor and sustain social capital and poorly performing partnerships that do not accomplish the expected sales" (Chetty and Agndal 2007, 12). This point is based on the argument by Nahapiet and Ghoshal (1998) that social capital may limit openness and access to new information. The liability role of social capital can lead to mode change in times when a firm has to respond to a negative situation in the market (Chetty and Agndal 2007). Chetty and Agndal (2007) found that the liability role of social capital was the most influential factor for post-entry mode change among their case firms. This was due to the inactivity of business partners, high maintenance costs with customers or distributors, failure with a joint venture partner, retirement of a partner, and so on. All in all, in the studies by Chetty and Agndal (2007) and Agndal et al. (2008), efficacious and direct social capital was attached to early FMEs, with serendipitous and indirect social capital being associated with later FMEs. Hence, the role of social capital changed with and was dependent on FMEs. Nevertheless, these three roles (serendipity, efficacy, and liability) are not mutually exclusive, since a specific mode change can be initiated by the various single or multiple roles of social capital (Chetty and Agndal 2007).

\section{Internationalization and social capital in family SMEs}

Researchers have found that family firms are less likely to internationalize than nonfamily firms (Fernandez and Nieto 2005; Graves and Thomas 2006). The reasons for this might be, for instance, their limited growth objectives (Donckels and Fröhlich 1991), 
avoidance of risk (Claver et al. 2008), and restricted financial capital (Gallo and Pont 1996). In addition, there could be a connection to limited managerial capabilities (Graves and Thomas 2006) and to a lack of bridging network ties (Graves and Thomas 2004). All in all, family involvement in management has been seen as factor tending towards caution in the internationalization processes of family firms (Claver et al. 2008; Kontinen and Ojala 2010). In practice, the internationalization of family firms is mainly incremental, i.e. proceeding step by step (Claver et al. 2008; Graves and Thomas 2008).

As regards social capital, it should be noted that family SMEs are less likely to form networks - that is, bridging social capital ties - with other businesses than are nonfamily SMEs (Graves and Thomas 2004; Roessl 2005). This tendency might well be connected to their extremely strong inner bonding social capital (Salvato and Melin 2008), which can be assumed to have an effect on the manner in which they build and develop bridging social capital. Their strong bonding capital is based on the unification of ownership and management (Salvato and Melin 2008): a family business incorporates the aspirations and capabilities of the family members, and the social element it embodies affects the decisions that determine its strategy, operations, and administrative structure (Chrisman et al. 2005). Family firms are oriented towards personal relationships, with a focus on interpersonal trust (Roessl 2005).

\section{Summary}

Scholars in the field of international entrepreneurship have called for research that would go beyond rapidly internationalizing firms (Dimitratos and Jones 2005; Young et al. 2003). Here, we study family-owned SMEs. In the disciplines of both international entrepreneurship and family business studies, networks and social capital have been seen as important (e.g. Coviello 2006; Graves and Thomas 2004). However, the bridging network ties of family SMEs have been studied to only a very limited extent (Arregle et al. 2007; Kontinen and Ojala 2010), despite their obvious importance, especially in the context of the internationalization of family firms. From earlier studies, it appears that the internationalization of family SMEs may differ from the internationalization of SMEs in general (see e.g. Fernandez and Nieto 2005; Graves and Thomas 2006). For this reason, it would seem useful to study bridging social capital when one is examining the specific features of family SMEs in relation to internationalization. In the present study we do this by moving from the broad concept of social capital to that of bridging social capital, applying the concepts in question to the internationalization of family SMEs.

\section{METHODS}

Since the objectives of the research reported here were more related to understanding the behavior of a firm than to quantitative measurement (Jack 2005), a qualitative research method was regarded as most appropriate for this study. A qualitative approach provides "understanding of what really goes on in networks; provides more knowledge about the content of network relations; the processes involved; how 
networks evolve, change and develop over time" (Jack 2010, 120). Hence, we used a multiple case study method, similar to the approaches introduced by Eisenhardt (1989), Eisenhardt and Graebner (2007), and Yin (1994).

The research setting was eight family firms operating in the French market with different operation modes. The number of cases is in line with Eisenhardt (1989), who recommends using four to ten cases. The selection of the firms for investigation was based on an overall theoretical perspective, as recommended in the study by Eisenhardt (1989). To be eligible as a case firm, the following criteria had to be fulfilled: 1) the firm was Finnish, 2) the firm had less than 250 employees at the time of the French market entry, hence fulfilling the criteria of the Finnish government and the EU for classification as an SME (OECD 2003), 3) the firm belonged to the manufacturing industry, 4) the firm was family-owned, with the family controlling the largest block of shares or votes, having one or more of its members in key management positions, and having members of more than one generation actively involved with the business $\left.{ }^{2}, 5\right)$ the firm had been doing business in the French market for more than five years. Suitable case firms were sought in different databases, including Finnish export statistics, and the databases of the French-Finnish Chamber of Commerce and Finpro (Finnish Export Promoting Organization) in Paris. We identified six SMEs that had direct operations in France, five of which were included in this study. The remaining three cases were family SMEs with indirect operations in France, selected from different geographical locations in Finland.

We selected market entry to the French market as the context of the FME. This allowed investigation of the FME in a context that would be similar for all the firms, bearing in mind that laws, regulations, and customs can vary in different markets (Shrader et al. 2000). In addition, it seems that France is a somewhat difficult market for Finnish family SMEs to enter, despite its market potential (Finpro 2008); hence the role of social capital could well be important in this context. Note also that social capital was studied in the context of SMEs, on the grounds that the determinants of social capital are more transparent in such enterprises. We thus follow Yin (1994) in selecting cases in which the phenomenon studied is transparently observable.

Table 1 summarizes the key information on the case firms. The firms were established between 1876 and 1988. The number of personnel varies from 18 to 249 employees, the average being 106 employees. France was generally entered at a fairly late stage in the internationalization pathways of the case firms.

Table 1. Information on the case firms.

\begin{tabular}{lllllll}
\hline & $\begin{array}{l}\text { Number of } \\
\text { employees }\end{array}$ & $\begin{array}{l}\text { Year } \\
\text { establishment }\end{array}$ & $\begin{array}{l}\text { of } \\
\text { internationalizati } \\
\text { on }\end{array}$ & $\begin{array}{l}\text { Number } \\
\text { countries } \\
\text { before France }\end{array}$ & $\begin{array}{r}\text { of } \\
\text { entered }\end{array}$ & $\begin{array}{l}\text { Operation modes in } \\
\text { France }\end{array}$ \\
\hline Firm A & 249 & 1876 & $1970 \mathrm{~s}$ & 5 & 1982 export \\
& & 1923 & 1929 & 7 & 1985 subsidiary \\
Firm B & 18 & 1967 & $1980 \mathrm{~s}$ & 4 & 1968 export \\
Firm C & 200 & & & & 1997 subsidiary
\end{tabular}

\footnotetext{
${ }^{2}$ This definition is based on the two criteria of ownership and management presented, for instance, by Graves and Thomas (2008), and on the factor of continuity (see for instance Zahra 2003).
} 


\begin{tabular}{llllll} 
Firm D & 20 & 1973 & $1990 \mathrm{~s}$ & 2 & 1998 export \\
Firm E & 140 & 1972 & $1980 \mathrm{~s}$ & $>10$ & $\begin{array}{l}\text { 2002 representative } \\
\text { 1989 export }\end{array}$ \\
& & & & & 2006 subsidiary \\
Firm F & 40 & 1988 & 1991 & 0 & 1991 subsidiary \\
Firm G & 30 & 1978 & 1980 & 4 & 1990 import \\
& & & & & 1991 export \\
Firm H & 150 & 1955 & $1990 \mathrm{~s}$ & 10 & 1993 export \\
\hline
\end{tabular}

Multiple sources of information were used to gather data from each case firm. The main form of data collection was in-depth interviews conducted with the ownermanagers and with persons in charge of international affairs. Altogether, 16 semistructured open-ended interviews, lasting from 60 to 90 minutes, were conducted with two informants from each firm. The interviewees were selected from those persons who had most in-depth knowledge concerning internationalization and operations in France, and they included executives (entrepreneurs), managing directors, managers of international affairs, and sales administrators. Following Svendsen (2006), at the beginning of the interview, neutral and non-threatening questions were asked to establish a relationship of mutual trust. The interviewees were first asked to describe their business in general, thereafter their operations related to internationalization as a whole, and from that the business connected to internationalization in France in particular. When the main issues of the interview were touched on, short questions such as "Could you describe this? How? Why?" were posed to go deeper into the issue. Social capital in the process of entry to the French market was discussed in relation to important events, persons, firms, or organizations that had enabled or influenced the foreign market entry and possible post-entry changes. All these questions were developed according to the guidelines issued by Yin (1994), with the aim of making the questions as non-leading as possible. This encouraged the interviewees to give authentic answers to the interview questions. Because the interviews focused on the entrepreneurs' past experiences, we followed the guidelines for retrospective studies issued by Miller et al. (1997), and by Huber and Power (1985).

All the interviews were digitally recorded and transcribed verbatim using a word processor. During the second listening, correspondence between the recorded and the transcribed data was ensured. The complete case reports were sent back to the interviewees, and any inaccuracies they noticed were corrected on the basis of their comments. In addition, e-mail communication was used to collect further information from the interviewees and to clarify inconsistent issues, if necessary. The respondents interviewed were personally involved in the FME process, except in the case of Firm D in which the person responsible for entry to the French market was deceased; here the interviewees were the person currently in charge of international affairs and the present owner-manager. However, the internationalization history of Firm D was well documented. In addition, many types of secondary information (websites and annual reports, etc.) were collected and analyzed. By comparing the interview data with other 
case firm documents, we carried out triangulation of the information obtained (Miles and Huberman 1994). This also increased the validity of the interview data and enabled us to formulate further questions to clarify incoherent information (Yin 1994).

The method utilized in the data analysis was content analysis. The analysis of the case data consisted of three concurrent flows of activity (Miles and Huberman 1994): 1) data reduction, 2) data displays, 3) conclusion drawing / verification. In 1) the data reduction phase, the data were focused and simplified by writing a detailed case history of each firm. This is in line with Pettigrew (1990), who suggests that organizing incoherent aspects in chronological order is an important step in understanding the causal links between events. Thereafter, on the basis of the interviews, the unique patterns of each case were identified and categorized into the patterns observed under the sub-topics derived from the research questions. Three tables were formed to encompass the data. In addition, checklists and event listings were used to identify critical factors related to the phenomena encountered (Miles and Huberman 1994). In 2) the data display phase, the relevant data were collected in matrices, graphs, charts, networks, and in Tables in Microsoft Excel. In 3) the phase of conclusion drawing and verification, we concentrated on identifying the aspects that appeared to have significance. At this stage we noted regularities, patterns, explanations, and causalities relating to the phenomena.

\section{FINDINGS AND DISCUSSION}

In this section, the findings of the study are presented and discussed according to the type and role of social capital in the case firms' market entry to France. The type of social capital was investigated in terms of the strength of the tie (strong or weak) and the structure of the relationship (formal, informal, or intermediary). The role of social capital was analyzed by attaching to each type the efficacy, serendipity, or liability role operating in the FMEs, plus the entry mode choice. Figure 1 summarizes the types, plus the roles of social capital in the FME. It also shows how social capital functions changed in the post-entry operations of four case firms (see right-hand boxes). 


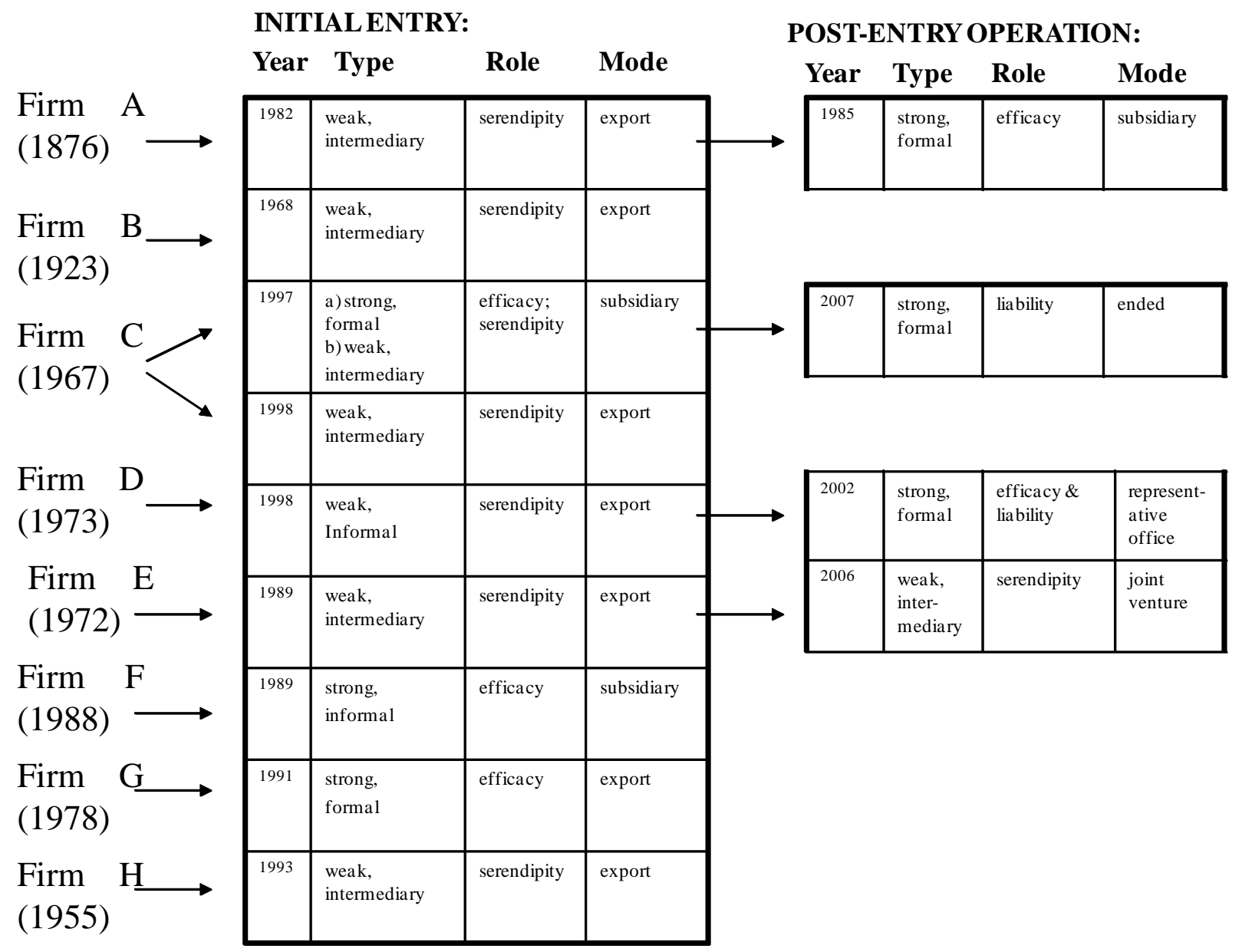

Figure 1. Type and role of social capital in the FME and post-entry operations of eight family SMEs.

\section{Type and role of social capital in the FME}

In most of the case firms (A, B, C, D, E, and H), the social ties in the FME could be considered weak. This indicates the importance of weak ties for family SMEs in the search for business opportunities in foreign markets. It also supports the ideas of Burt (1992, 2004) and Granovetter (1973) to the effect that unique information emerges through weak ties. It is further consistent with the findings of Agndal et al. (2008), indicating that indirect ties play a more important role in later market entries. To give an example, in the case of Firm D, the circumstances around finding the weak tie were the following:

"A French guy happened to be in the countryside where one of our Finnish sales agents was presenting one of our log houses. He insisted on starting to sell our log houses in France. My sales agent phoned me about it and I (the owner-manager) said okay, he can come and meet me. Well, then I went to see him and after some negotiations I said okay, just go ahead and start 
selling our log houses. Of course I did not know him at all at that point, but it felt like he was a good guy." (Firm D, owner-manager)

In all these six cases with weak ties (firms A, B, C, D, E, and H), social capital had a serendipity role. This is in line with Chetty and Agndal's finding (2007) that unexpected events are commonly triggered by weak ties. It also gives support to the findings of Agndal et al. (2008) that the serendipity role is more dominant in later market entries, and if a firm is entering psychologically distant ${ }^{3,4}$ markets. In addition, the strong role of serendipity in FMEs indicates good managerial capabilities in the case firms that allow them to take advantage of new opportunities (cf. Crick and Spence 2005). For instance, the owner-manager of Firm D was willing to seize the offer given by the French person "Okay, just go ahead and start selling our log houses." Similarly in the case of Firm A, when their future French agent contacted them just after they had met at an international exhibition, they were able to take up the offer without delay:

"In those international exhibitions we met many kinds of potential cooperators from different countries. This French partner seemed very pleasant and trustworthy and showed genuine interest in our products. [...] Our product suited their product range perfectly. We had a new, innovative product that other European firms imitated later on, and it was of great interest to this retailer. We felt this was a good opportunity, and we were even happier when this partner contacted us himself soon after the exhibition, and our cooperation started soon after that." (Firm A, international sales manager)

Five out of the six case firms with weak ties used intermediary relationships for their market entry (firms A, B, C, E, and H) and one (firm D) an informal relationship. Hence, the FME was generally triggered by a third party not previously known to the case firm. This finding is in line with Ojala (2009), who found that intermediary relationships are important if a firm does not have existing relationships which it can utilize for the FME. In Firms A, B, E, and H, this intermediary contact was made at an international trade exhibition, thus demonstrating the importance of trade exhibitions in the search for suitable partners. One of the informants in Firm A described it this way:

"Recently, I've been thinking of our international co-operators, and, indeed, most of them are people we've found at international trade exhibitions. There, people can see, okay, there's this kind of product as well, and they come and ask if we already have representatives.[...] That was how it went with the French, too."

In Firm C, the weak and intermediary tie was found via Finpro (Finnish Export Promoting Organization). Firm C contacted Finpro Paris to find out if they had any potential candidates to market and sell their product in France. A Finnish woman living permanently in France, someone who had also worked for the Finpro Paris office, was

\footnotetext{
${ }^{3}$ There are important cultural and linguistic differences between France and Finland, see e.g. Irrmann (2006) amd Trompenaars and Hampden-Turner (1997).

${ }^{4}$ Johanson and Wiedersheim-Paul $(1975,308)$ define psychic distance as "factors preventing or disturbing the flow of information between firm and market."
} 
found through this search. She was one of two important persons enabling the entry of Firm $\mathrm{C}$ to France. The other person was a strong and formal tie, a Finnish entrepreneur who also facilitated the entry (discussed in more detail later in this section). The French co-operator described the sequence as follows:

"I had been working for Finpro just before I heard from my colleagues in Finpro that a firm (Firm C) was looking for someone to establish their business in France. I became interested in that right away, since I was looking for a job and this firm seemed nice and interesting."

In the case of Firm D, too, the central tie was weak but informal (as opposed to intermediary), as the person initiating the French FME was met by coincidence. A French entrepreneur living in Finland met the representative of Firm D in one of its log houses (i.e. the product of Firm D). The French entrepreneur was keen on exporting the $\log$ houses to France, since he saw that the French market had potential for this kind of product.

It was only in Firms F and G, that the FME to France was based solely on strong ties, in other words ties developed through interactions over time. In addition, one of the two ties essential in the FME of Firm C was strong, whereas the other one (discussed above) was weak and intermediary. All of these three strong ties derived from what had originally been a business-based relationship. However, in Firm F, this tie had developed into an informal one, as the entrepreneur in Firm $\mathrm{F}$ had become a good friend of the subsidiary manager of the French subsidiary. Hence, it is classified as an informal tie. This demonstrates the dynamic nature of social capital, with the possibility that the nature of ties can change over time (cf. Larson and Starr 1993). The entrepreneur in Firm F described the strong relationship as follows:

"We were good friends. It was very natural that we would start to cooperate after I launched my new firm. Well, it happened spontaneously, because we were such good friends. I don't even know who asked first, me or him. He wanted to work for me and not for my previous firms, which had been taken over, so he resigned right away when he heard about my new firm. [...] Over all these years, I have got to know him extremely well. We can trust each other 100\%, we have respect for each other's opinions, have similar kinds of values in life and are interested in similar kinds of things. [...] We do not communicate that often, but we can always proceed from where we left off last time."

In Firms $C$ and $G$, the strong tie was obviously formal. In Firm C, it was based on a Finnish entrepreneur who had agreed to utilize $C^{\prime}$ s forest machinery in France, and at the same time, to promote it there.

"Well, we found a young and eager entrepreneur in Finland who took two friends with him and starting working there [in France] with our machine. We sold him the machine at a reasonable price. [...] Then he found some work there and started to earn money, actually better than in Finland."

In the case of Firm G, the initiator of the foreign market entry was their formal contact, the French supplier who imported their products. The owner-manager of the firm commented on this as follows: 
"They wanted us to provide them with some of our products, items they did not produce there in France. That is how we started to export to France."

In all of these case firms with strong ties, social capital played an efficacy role. Hence, the FME was based on the proactive exploitation of the strong social capital ties where information on business opportunities in France had come through partners who were well known to the firm. For Firm F, France was the first country which it entered, demonstrating the efficacy role of social capital in initial market entries (see Agndal et al. 2008).

\section{Type and role of social capital in post-entry mode change}

In Firms $\mathrm{A}, \mathrm{C}, \mathrm{D}$, and $\mathrm{E}$, a post-entry mode change occurred after the initial entry to the French market. In three out of four cases (Firms A, C, and D), the mode change was based on strong and formal social ties, social capital now having efficacy and/or liability roles. Firm A established a French subsidiary because their French partners were good and trustworthy, indicating the efficacy role of social capital. One of the informants in Firm A described the matter in the following way:

"We ended up setting up a subsidiary after two or three years of exporting, because they were doing so well and we wanted them to concentrate only on our products. The manager of this subsidiary was a very good type of person and we had confidence that it was worth investing money on this firm. And everything has gone extremely well ever since."

This supports the findings of Chetty and Agndal (2007), that increasing social capital between partners can trigger post-entry mode change, from a low-control mode to a high-control mode. In Firm D, both the efficacy and liability roles of social capital were present when a representative office was set up. The efficacy role refers to the French entrepreneur who initiated the entire French entry, and who was seen as a person who could be trusted to set up a representative office. However, the liability role of social capital was also centrally present in this context: Firm D initially wanted to form an extensive network of French retailers to represent their products. They tried dozens of retailers, but failed to achieve cooperation. Because of these difficulties, they saw it as necessary to take care of the French trade themselves, and they ended up establishing a representative office. This demonstrates that the differing roles of social capital can be overlapping and exist simultaneously. The entrepreneur in Firm D explained the matter as follows:

"We started by searching for local partners who would look for customers. They told us about the needs of the customers, we made the offers and they passed them on to customers. We tried this and that with these potential partners for many years, but none of them turned out to be trustworthy or able to sell. They just took our time and money. On one of the trips we went to Paris and met a man who ordered thirty log houses. And none of them were actually delivered. He just cheated us... But luckily I had him (the French agent) and we established a representative office in France." 
In a similar manner to Firm D, Firm $C$ did not have a strategy or suitable networks to sell their forest machinery in France or in any other countries with success. Hence, they closed their subsidiary, and the role of social capital in this case can be regarded as a liability role. This was connected with several problems encountered in the French market. One of the informants in Firm $C$ saw this as more of a strategic problem: Firm $\mathrm{C}$ was not able to sell forest machines globally and achieve financial profitability. Taking a contrasting view, the French subsidiary manager of Firm $\mathrm{C}$ saw the matter more as a communication problem and as involving a lack of cooperation between the headquarters and the subsidiary.

Firm E was the only enterprise in which the ties initiating the entry mode change were weak and intermediary, and in which social capital played a serendipity role. Exports of goods to France had encouraged the owner-manager of Firm E to look for new opportunities in France. However, the firm did not find that any of its existing agents in France had the potential to set up a subsidiary. In the end, the firm's joint venture partner was found through a French organization (Invest in France). Furthermore, the establishment of the production joint venture in France was a strategic choice:

"It is natural that if you are abroad and you just sell, you often do not sell that much, because you also have other products to sell. When you set up a production subsidiary, the nature of selling changes totally - you need to sell all you produce. It's totally different from the situation of selling however much you like. [...] We were lucky to find this Invest in France organization that helped us so much in finding a good partner in France. We had a couple of alternatives, and ended up with one of them. We knew we needed to be in France and Invest in France made it possible to find an excellent partner with whom to establish a joint venture.

This is in line with Chetty and Agndal's study (2007), indicating that weak ties have a central role in serendipitous events. However, this finding also reveals the intermediary role of export/import promotion organizations in entry mode change and serendipity events.

\section{CONCLUSIONS}

This study contributes to the fields of international entrepreneurship and family business studies. Firstly, by studying family SMEs, it expands international entrepreneurship studies beyond early internationalizing firms, answering the call for research beyond rapidly internationalizing firms (Dimitratos and Jones 2005; Young et al. 2003). Note here that family firms are to be regarded as entrepreneurial firms, although they usually internationalize in a later phase of their life cycle. Secondly, this study investigates bridging social capital - a topic not hitherto covered in family business studies. It is clear that family SMEs with strong, inner bonding networks also need bridging networks when they internationalize. For this reason, it is important to see how they use social capital in this context. Thirdly, the findings here validate and also build on the studies by Chetty and Agndal (2007) and Agndal et al. (2008), in so far 
as they demonstrate how the roles and types of social capital affect FME and entry mode change among family SMEs. Our findings relate to what are, in research terms, a new group of firms (family SMEs), and the FME context is extended to a particular market rather than involving the general pattern of internationalization. In addition, this paper responds to the call of Pedersen et al. (2002) for investigations into post-entry mode changes after the initial FME. In addition to focusing on the FME, the study also looked at social capital in the context of post-entry operations. On a more detailed level, the study elaborated the effect of social capital on foreign operation mode changes.

In this study, social capital generally had a serendipity role, based on weak and intermediary relationships among the case firms. The intermediary ties were most often initiated at international trade exhibitions. Three out of the eight case firms were able to utilize existing strong relationships for the FME, social capital in these cases taking on an efficacy role. However, most family SMEs do not have international ties, and they need to develop them for the FME.

As regards post-entry mode changes, the role of strong and formal ties was obvious, and social capital generally had efficacy or liability roles. There was only one post-entry change towards the use of intermediary ties, and to a serendipity role. From this it would appear that in most cases, family SMEs concentrate on developing trustworthy relationships. If they succeed in this, they may change their mode of operation from indirect to direct. Generally speaking, family SMEs do not seem to concentrate on finding new international ties once they have acquired the necessary contact to operate in the market in question.

Overall, it seems that the social capital of family entrepreneurs is limited to their strong bonding social capital and, perhaps, to their strong national social capital. When they do internationalize, they generally need to find new networks to collect some bridging social capital, in order to make the FME possible. This is a resource that they usually do not have initially. These considerations underline the need for more research on the bridging social capital of family SMEs if we are to gain an understanding of the role of social capital in their FMEs and in their other operations.

Although our study provides an empirical contribution to the topic of social capital in the FME and post-entry operations of family SMEs, there is plenty of scope for further research. As a first step, a similar kind of a study could be conducted in some other cultural contexts. This could cast more light on the effect of the cultural context on the issue. Secondly, once a comparative study has been conducted in several countries, there is a need for quantitative testing, since the findings of this study cannot be very widely generalized due to the methodological circumstances. Thirdly, our research setting limits the case firms to family-owned SMEs. Although this approach has the advantage of a specific focus, one would clearly wish to take the research into broader contexts. Thus, further studies are needed in relation to social capital ties of early internationalizing firms and firms that have different kinds of ownership structures. In addition, there is a need for comparative studies between family SMEs and non-family SMEs. 
Regarding the possible limitations of the study, there are some aspects that might differ depending on the home and target country. For instance, it seems that some firms (from China, India, Vietnam, etc.) are able to take advantage of their emigrant relationships around the world (Bagwell 2008; Child et al. 2002; Prashantham and Dhanaraj 2010). In these cases, transnational family ties (Bagwell 2008; Tsang 2001) may have a greater effect on network formation and development than was the case in the present study. In addition, the cultural and psychic distances between countries may affect how firms establish and develop network ties; as the psychic distance between countries increases, network formation becomes more difficult (Johanson and Vahlne 2009) and firms have to find alternative ways to find and establish network ties (Ojala 2009).

\section{Managerial implications}

International trade exhibitions offer a good context for family SMEs to create ties leading to international markets. They offer excellent possibilities to network with international operators in the same industry, which in turn may give them access to new foreign markets. Another option for international networking is export-promotion organizations; these may be able to mediate relationships between family SMEs and potential foreign customers or distributors. They can provide firms with overall market data and with some contact details, and from these the firms can start the search for cooperators. Although the ties found in these kinds of contexts are initially weak, they can be built up to become strong and trusted, enabling the further development of international operations. For instance, an agent can become a subsidiary manager or a joint venture partner.

Another relevant point here is that family entrepreneurs should take advantage of their ability to react serendipitously: when an offer for cooperation comes from a potential social capital tie, they have the possibility to seize hold of the opportunity in a flexible fashion, in contrast to firms with more formal organizational and management structures. One can also suggest that family firms should take full advantage of their actual presence in the foreign market: given their flexibility and personal contacts, they have possibilities to network with customers and other actors, persons whom they may need in future for other purposes. These foreign customers can act as a source for recognizing new business opportunities, and they can help with localizing a firm's product for the specific needs of customers in the country in question.

\section{References}

Adler PS, Kwon S-W (2002) Social capital: Prospects for a new concept. Academy of Management Review 27(1):17-40.

Agndal H, Chetty S, Wilson H (2008) Social capital dynamics and foreign market entry. International Business Review 17(6):663-675. 
Arregle J-L, Hitt MA, Sirmon DG, Very P (2007) The development of organizational social capital: Attributes of family firms. Journal of Management Studies 44(1):73-95.

Bagwell S (2008) Transnational family networks and ethnic minority business development: The case of Vietnamese nail-shops in the UK. International Journal of Entrepreneurial Behaviour \& Research 14(6):377-394.

Burt RS (1992) Structural Holes, Cambridge: MA: Harvard University Press.

Burt RS (2004) Structural Holes and Good Ideas. American Journal of Sociology 110(2):349-399.

Chetty S, Agndal H (2007) Social Capital and Its Influence on Changes in Internationalization Mode Among Small and Medium-Sized Enterprises. Journal of International Marketing 15(1):1-29.

Chetty SK, Wilson HIM (2003) Collaborating with competitors to acquire resources. International Business Review 12(1):61-81.

Child J, Ng SH, Wong C (2002) Psychic distance and internationalization: Evidence from Hong Kong firms. International Studies of Management \& Organization 32(1):36-56.

Chrisman JJ, Chua JH, Steier L (2005) Sources and Consequences of Distinctive Familiness: An Introduction. Entrepreneurship Theory and Practice 29(3):237-247.

Claver E, Rienda L, Quer D (2008) Family firms' risk perception: Empirical evidence on the internationalization process. Journal of Small Business and Enterprise Development 15(3):457-471.

Coleman JS (1988) Social Capital in the Creation of Human Capital. American Journal of Sociology 94:S95-S120.

Coviello N (2006) The network dynamics of international new venture. Journal of International Business Studies 37(5):713-731.

Coviello N, Munro H (1997) Network Relationships and the Internationalisation Process of Small Software Firms. International Business Review 6(4):361-386.

Crick D, Spence M (2005) The internationalisation of 'high performing' UK high-tech SMEs: a study of planned and unplanned strategies. International Business Review 14(2):167-185.

Dimitratos P, Jones M (2005) Future directions for international entrepreneurship research. International Business Review 14(2):119-128.

Donckels R, Fröhlich E (1991) Are family businesses really different? European Experiences from STRATOS. Family Business Review, 12(2):146-160.

Dyer WGJr (2003) The Family: The Missing Variable in Organizational Research. Entrepreneurship Theory and Practice 27(4):401-416.

Eisenhardt KM (1989) Building theories from case study research. Academy of Management Review 14(4):532-550.

Eisenhardt KM, Graebner ME (2007) Theory Building from Cases: Opportunities and Challenges

Ellis P (2000) Social Ties and Foreign Market Entry. Journal of International Business Studies 31(3):443-469.

Fernandez Z, Nieto MJ (2005) Internationalization strategy of small and medium-sized family businesses: Some influential factors. Family Business Review 18(1):77-89. 
Finpro (2008) Subsidiaries of Finnish companies in France - July 2008.

Gallo MA, Pont CG (1996) Important factors in family business internationalization. Family Business Review 9(1):45-59.

Granovetter MS (1973) The Strength of Weak Ties. American Journal of Sociology 76(6):1360-1380.

Granovetter MS (1985) Economic action and social structure: The problem of embeddedness. American Journal of Sociology 91(1):481-493.

Granovetter MS (1992) Problems of explanation in economic sociology. In N Nohria and R Eccles (Eds.), Networks and organizations (25-56). Boston, MA: HBS Press.

Graves C, Thomas J (2004) Internationalisation of the family business: a longitudinal perspective. International Journal of Globalisation and Small Business 1(1):7-27.

Graves C, Thomas J (2006) Internationalization of Australian family businesses: A managerial capabilities perspective. Family Business Review 19(3):207-224.

Graves C, Thomas J (2008) Determinants of the internationalization pathways of family firms: An examination of family influence. Family Business Review 21(2):151-167.

Hite JM (2003) Patterns of multidimensionality among embedded network ties: a typology of relational embeddedness in emerging entrepreneurial firms. Strategic Organization, 1(1):9-49.

Huber GP, Power DJ (1985) Retrospective Reports of Strategic-level Managers: Guidelines for Increasing their Accuracy. Strategic Management Journal 6:171-180.

Irrmann $O$ (2006) Intercultural communication and the integration of cross-border acquisitions. Doctoral dissertation. Helsinki School of Economics, Helsinki.

Jack SL (2005) The Role, Use and Activation of Strong and Weak Network Ties: A Qualitative Analysis. Journal of Management Studies 26(6):1234-1259.

Jack SL (2010) Approaches to studying networks: Implications and outcomes. Journal of Business Venturing 25:120-137.

Johanson J, Vahlne J-E (2006) Commitment and opportunity development in the internationalization process model. Management International Review 46(2):165-178.

Johanson J, Vahlne J-E (2009) The Uppsala internationalization process model revisited: From liability of foreignness to liability of outsidership. Journal of International Business Studies, 40:1411-1431.

Johanson, J, Wiedersheim-Paul F (1975) The internationalization of the firm: Four Swedish cases. Journal of Management Studies 12(3):305-322.

Kontinen T, Ojala A (2010) The internationalization of family businessess: A review of extant research. Journal of Family Business Strategy 1(2):97-107.

Krackhardt D, Hanson JR (1993) Informal Networks: The Company Behind the Chart. Harvard Business Review 71(4):104-111.

Larson A, Starr JA (1993) A Network Model of Organization Formation. Entrepreneurship Theory and Practice 17(2):5-15.

Marsden PV, Campbell KE (1984) Measuring tie strength. Social Forces, 63(2):482-501.

Miles MB, Huberman AM (1994) Qualitative Data Analysis: An Expanded Sourcebook. California: Sage Publications. 
Miller CC, Cardinal LB, Glick WH (1997) Retrospective reports in organizational research: A reexamination of recent evidence. Academy of Management Journal 40(1):189-204.

Nahapiet J, Ghoshal S (1998) Social Capital, Intellectual Capital, and the Organizational Advantage. Academy of Management Review 23(2):242-266.

OECD (2003) Officially-supported export credits and small exporters. Organization for Economic Co-operation and Development, Paris, France.

Ojala A (2009) Internationalization of knowledge-intensive SMEs: The role of network relationships in the entry to a psychically distant market. International Business Review 18(1):50-59.

Oviatt BM, McDougall PP (2005) Defining international entrepreneurship and modeling the speed of internationalization. Entrepreneurship Theory and Practice 29(5):537553.

Prashantham S, Dhanaraj C (2010) The Dynamic Influence of Social Capital on the International Growth of New Ventures. Journal of Management Studies 47(6):967994.

Pedersen T, Petersen B, Benito G (2002) Change of Foreign Operation Method: Impetus and Switching Costs. International Business Review 11(3):325-345.

Pettigrew AM (1990) Longitudinal field research on change: Theory and Practice. Organization Science 1(3): 267-292.

Portes A (1998) Social Capital: Its Origins and Application in Modern Sociology. Annual Review of Sociology 24(1):1-24.

Rauch JE (2001) Business and Social Networks in International Trade. Journal of Economic Literature 39(4):1177-1203.

Roessl D (2005) Family Businesses and Interfirm Cooperation. Family Business Review 18(3):202-214.

Salvato C, Melin L (2008) Creating Value Across Generations in Family-Controlled Businesses: The Role of Family Social Capital. Family Business Review 21(3):259-276.

Sciascia S, Mazzola P, Astrachan JH, Pieper T (in press) The role of family ownership in international entrepreneurship: exploring nonlinear effects. Small Business Economics.

Shrader RC, Oviatt BM, McDougall PP (2000) How new ventures exploit trade-offs among international risk factors: Lessons for the accelerated internationalization of the 21st century. Academy of Management Journal 43(6):1227-1247.

Singh RP (2000) Entrepreneurial Opportunity Recognition Through Social Networks. New York: Garland Publishing.

Sobel J (2002) Can We Trust Social Capital? Journal of Economic Literature 40(1):139-154.

Svendsen GH (2006) Studying social capital in situ: A qualitative approach. Theory and Society 35:39-70.

Söderqvist A, Chetty S (2009) Strength of ties and their role in pre-founding, start-up and early internationalization. Paper presented at $12^{\text {th }}$ McGill International Entrepreneurship Conference, Vaasa, Finland. 
Trompenaars F, Hampden-Turner C (1997) Riding the waves of culture: Understanding cultural diversity in business. Nicholas Brealey (2nd ed.), London

Tsang EWK (2001) Internationalizing the family firm: A case study of a Chinese family business. Journal of Small Business Management 39(1): 88-94.

Walker G, Kogut B, Shan W (1997) Social Capital, Structural Holes and the Formation of an Industry Network. Organization Science 8(2):109-125.

Yin RK (1994) Case study research: Design and methods (2nd ed.), Newbury Park, CA: SAGE Publications.

Yli-Renko H, Autio E, Tontti V (2002) Social Capital, Knowledge, and the International Growth of Technology-Based New Firms. International Business Review 11(3):279304.

Young S, Dimitratos P, Dana LP (2003) International Entrepreneurship Research: What Scope for International Business Theories? Journal of International Entrepreneurship $1(1): 31-42$.

Zahra SA (2003) International expansion of U.S. manufacturing family businesses: The effect of ownership and involvement. Journal of Business Venturing 18(4):495-512. 